\title{
FINDING THE KEY TO SUCCESS: A VISITORS' PERSPECTIVE AT A NATIONAL ARTS FESTIVAL
}

\author{
Melville Saayman: TREES (Tourism Research in Economic Environs and Society), North-West \\ University. \\ Martinette Kruger: TREES (Tourism Research in Economic Environs and Society), North-West \\ University. \\ Joffrey Erasmus: TREES (Tourism Research in Economic Environs and Society), North-West \\ University.
}

Purpose and/or objectives: The purpose of this article was to segment festival visitors at the Klein Karoo National Arts Festival (KKNK) based on their travel motives and their ratings of the Key Success Factors (KSFs) in terms of their festival experience.

Problem investigated: Previous research has indicated that the success and sustainability of an arts festival is dependent on the number of tickets sold for shows and productions during the festival. Therefore, success depends on attracting visitors who attend and buy tickets for different types of shows and productions. To achieve this festival organisers need to understand the aspects that visitors regard as satisfying their needs and which create a unique festival experience.

Methodology: A survey was conducted using a questionnaire at the festival. A total of 450 questionnaires were administered and 443 completed questionnaires were included in the analysis. Factor analysis was used to identify visitors' motivation to travel to and attend the KKNK. Cluster analysis followed the factor analysis to segments visitors based their identified travel motives. ANOVAs, Chi-square tests, two-way frequency tables and Tukey's multiple comparisons were conducted to investigate and determine any significant differences between the clusters based on demographics, behavioural variables and KSFs.

Analysis and interpretation of findings: The findings of this study revealed that the travel motives that are important to visitors to the arts festival are: Festival Attractiveness, Novelty and Escape and Socialisation. Furthermore, different markets have different travel motives, clustered as Escapists, Festival Junkies and Culture Seekers. These different clusters have different tastes and needs, for example the Culture Seekers are more interested in Rock shows and all three clusters enjoy Drama, Music Theatre and Cabaret and Comedy shows and productions. Different markets also focus on different KSFs that influence their experience of the event. Escapists rated Venues and Shows and Stalls as the most important KSF in managing the festival, whereas Festival Junkies and Culture Seekers rated Safety and Personnel and Shows and Stalls as the most important.

The value of the research: This research provides several insights. First, travel motives are a good base or foundation for segmenting visitors to arts festivals. Hence, it is important to have an in-depth understanding of why visitors attend the arts festival and what they expect to experience at the arts festival. Second, this research makes a contribution to the literature around travel motives, market segmentation, festival management and need satisfaction. Finally, the results show that festival organisers cannot base their planning on a general evaluation of visitors, but that different markets have different needs and also regard different factors are important to their overall experience.

Conclusion: This research can help festival organisers understand what visitors want to experience at an arts festival and how they want to experience it.

Key words: Klein Karoo National Arts Festival, market segmentation, travel motives, festival experience, KSFs, cluster analysis, factor analysis, ANOVA, Chi-square tests

\section{INTRODUCTION}

The aim of this study is to determine if different markets (groups of visitors) to the Klein Karoo National Arts Festival (KKNK) have different Key Success Factors (KSFs) that influence their festival experience. This uses the premise that different markets have different requirements (Marais, 2009). 
This type of research is required because there are a growing number of offerings of leisure experiences, new markets are more specialised and competition is increasing, with festivals being established around the country, each with its own unique characteristics and objectives (Woodside and Martin, 2008:198).

One such festival is the KKNK, which has been held annually in Oudtshoorn, in the Western Cape for 16 years. It takes place during the April school holidays. Annually, more than a 1000 artists perform and exhibit at the KKNK in more than 200 shows and exhibitions over a period of eight days (Erasmus, Saayman, Saayman, Kruger, Viviers, Slabberte and Oberholzer, 2010:2). According to Hauptfleisch (2001:173) and Kitshoff (2004:237) the main aim of the KKNK is to promote culture and arts in Afrikaans by providing opportunities for the local community to take part in the arts festival, to benefit from the arts festival and to increase their life standards. Shows/genres that can be seen at the KKNK include music, visual arts, theatre productions, dance items and shows and African culture shows (Erasmus et al., 2010:1). The KKNK is, furthermore, seen as the largest arts festival in South Africa according to the economic impact on the host community and in 2010 the festival generated an estimated R109,7 million (Erasmus et al., 2010:36).

Even though arts festivals are held for different reasons visitors are in search of a total experience, which is made up of different factors such as the attractions, the shows, the variety of entertainment, restaurants and what they offer, and the opportunity to meet new people and experiencing Afrikaans culture in a unique way (Saayman, Marais and Krugell, 2010:95). Different visitors have different requirements and travel motives and reasons for attending an arts festival (Kruger, 2010:34) which lays the foundation for this research. For the KKNK to be sustainable, organisers should base their plans on the needs of visitors and ensure that these needs are met (Bowdin, Allen, O'Toole and McDonnel, 2006:265; Yu and Huat, 1995:375; Leiper, 2004:170; Van Zyl, 2006:150).

\section{THEORETICAL BACKGROUND}

Prentice and Anderson (2003:9) warn that not everyone who is at a festival can be assumed to be a festival goer, and they caution about making the assumption that all festival visitors are motivated to visit the destination to participate in the festival. Some are motivated, for example more by socialisation than by supporting the arts. Scott (1996) and Rachael and Douglas (2001) have shown that travel motives differ from festival to festival or attraction to attraction. Therefore, segmenting festival visitors based on their motivations is a prerequisite to an effective marketing strategy to optimise the use of marketing and promotional resources (Crompton and McKay, 1997:426; Juwaheer, 2006:4; Boo and Jones, 2009:66). Saayman (2001:12) defines travel motives as needs or wants that drive, push and steer a tourist or visitor to make a decision about a specific destination or attraction. According to Lee (2000:169) and Kim, Borges and Chon (2006:957) an analysis of travel motives for festival attendance is an important marketing tool or variable for market segmentation and effective promotion. Backman, Backman, Uysal and Sunshine (1995), Kara and Kaynak (1997:873) and Formica and Murrmann (1998:204) support this idea and conclude that festival visitors are not homogeneous when it comes to motives and that festival organisers should consider motives when profiling the target market and designing the festival programme.

From a festival organisers' perspective, the most desirable visitors to attract are those who stay longer, travel for the purpose of attending the festival, and who are likely to spend money supporting the festival shows/productions. For this reason, it is has become critical to select, attract and retain the most viable target market(s) (Mykletun, Crotts and Mykletun, 2001:494; Koc and Altinay, 2007:228). These factors have also become increasingly important as the growing number and diversity of festivals and events has led to heightened competition. Crompton and McKay (1997:426) and Van Zyl (2005:73) state that the enhancement and maintenance of visitors' central motives should be the primary goal of festival organisers, since identifying and prioritising motives is a key ingredient in understanding visitors' decision processes. Visitors may have several different needs, which they desire to satisfy by attending a festival and different visitors may engage in the same festival element 
and derive different benefits from the experience. Measuring the main desires that visitors are seeking to satisfy at the festival, and which motives lead to the preference of the particular festival, can give a more detailed profile of the visitors and enable marketers/organisers to better address their needs with a tailor-made and cost-effective marketing and festival programme (Crompton and McKay, 1997:426; Raybould, 1998:238; Gitelson and Kerstetter, 2000:179). Getting feedback from visitors on the aspects that influence their experience is therefore paramount in achieving growth of festivals (Saayman et al., 2010:98).

This first problem that faces event organisers and academics alike is that the reasons for attending a festival differ. These reasons include motives such as family togetherness, socialisation, novelty, excitement and escape (Park, Reisinger and Kang, 2009; Kim, Burgess and Chon, 2006; Formica and Murrmann, 1998; Nicholson and Pearce, 2001; Lee, 2000; Crompton and McKay, 1997; Schneider and Backman, 1996:143; Scott, 1996; Backman et al., 1995; Uysal, Gahan and Martin, 1993; Cha, McCleary and Uysal, 1995:35-37; Kruger and Saayman, 2008; Formica and Uysal, 1998; Formica and Uysal, 1996; Mohr, Backman, Gahan and Backman, 1993; Uysal, Gahan and Martin, 1993; Van Zyl, 2006:151). Hence, the motives visitors have for attending are critical in planning an event. Previous research has shown that the analysis of travel motives helps event organisers to better position their work (Scott, 1996); plan and market festival programmes effectively (Kim, Uysal and Chen, 2002:129); predict visitors' future travel patterns (Cha, McCleary and Uysal, 1995:33; Jang and Wu, 2006:314); identify markets in which visitor motives and festival features and resources match (Bansal and Eiselt, 2004:388); monitor satisfaction and understand visitors' decision processes (Crompton and McKay, 1997:426); respond to the changing needs and trends of the market (Ferrell, Hartline and Lucas, 2002:74); identify strengths and opportunities with a view to ensuring visitors' satisfaction (Lee and Lee, 2001); initiate improvements for increased visitor numbers and/or revenues such as a tailor-made festival programme designed to meet the needs of the visitors (Baker and Crompton, 2000; Crompton and McKay, 1997:426) and strengthen management and product development (Gnoth, 1997:283; Raybould, 1998:238).

The second problem or challenge, according to Saayman et al. (2010:96) is that arts festivals are a combination of numerous factors and elements that need to be managed effectively to create a unique experience for visitors. These include, for example, the theme of the festival, providing a variety of entertainment, and technical aspects, such as supplying food and beverages, marketing, managing stalls, managing the entrance, managing the visitors, transport services, information services, the layout of the arts festival, adequate accommodation, financial services, adequate parking areas, inclusion of the local community, adequate and trained staff, emergency and medical services, adequate and affordable children's activities, safety and security, managing ticket sales, adequate and correct directions, high quality infrastructure, and the different venues of shows and productions during the arts festival (Silvers, 2004:41; Matthews, 2008:2-347; Bowdin et al., 2006:353; Woodside and Martin, 2008:206). The afore-mentioned factors should be managed in such a way that they ensure a unique experience for visitors (Westerbeek, Smith, Turner, Emery, Green and Van Leeuwen, 2006:41). According to Page (2003:249) management is a function where the organisations' resources are used to deliver products, and services that meet tourists' needs. Therefore festival organisers should manage the different aspects of the KKNK to create an unforgettable festival experience.

In this regard it is important to determine what aspects or key success factors (KSFs) visitors regard as important for a quality visitor experience. Slabbert and Saayman (2003:8) define key success factors as the particular strategy elements, resources, competitive capabilities, product attributes, competencies, and business outcomes that spell the difference between profit and loss. Essentially, KSFs are thus the "must-achieve" factors and necessary for an organisation (festival) to achieve its overall goals (Brotherton, Miller, Heinhuis and Medema, 2002:48). However, key success factors are not business objectives or goals. They are combinations of activities or processes designed to support the achievement of such desired outcomes specified by the festival's objectives or goals (Brotherton and Shaw, 1996:114; Thompson and Strickland, 1999:96; Aaker, 2005:91). The emphasis on achievement highlights an important characteristic of KSFs, namely that they are action-orientated. 
Festival managers are furthermore entrusted with the responsibility to achieve the festivals' objectives, keep up management standards and ensure visitor satisfaction (Yu and Huat, 1995:375; Leiper, 2004:170); understanding of KSFs will make it easier to maintain these responsibilities and ensure a quality visitor experience.

Management theory shows that management in essence consist of four basic functions namely, planning, organising, leading and controlling (Murphy and Murphy, 2004:50; Leiper, 2004:175-179; Saayman, 2007:71; Vallen and Vallen, 2005:84). The most important function to ensure the success of a festival according to Saayman (2009:214) is the ability of the festival organisers to evaluate. Evaluation is often avoided but through evaluation or control, organisers not only determine their success but also failures and gaps (Saayman et al., 2010:97). The success depends on whether plans in terms of goals and objectives are reached, if high quality services and shows are provided, if the overall satisfaction of visitors are achieved, if a unique experience is offered, ensuring the festival programme satisfies all role players at the festival and if the overall festival is an improvement on the previous year's festival (Van der Westhuizen, 2003; De Witt, 2006; Goodman, Fandt, Michlitsch and Lewis, 2007; Daft and Mrcic, 2009). Kreitner (1989) defines control or evaluation as taking the correct action and ensuring the festival occurs as it was planned to occur. This therefore shows a strong relationship between planning and control which is indicated in Figure 1.

This relationship consists of three different phases during the evaluation plan. First, the input phase followed by the process and lastly the output phase. According to Figure 1 input consists of the festival visitors who are one of the most important stakeholders since they are the ones that buy tickets and support the arts and lead to the KKNK's success. These visitors differ based on their sociodemographic profile, behavioural characteristics and have different travel motives and reasons why they attend this specific arts festival. These motives include: to get away from their daily routine, to relax, to spend time with friends and family and to view a wide variety of shows and productions to name but a few. However, a quality visitor experience is especially dependent on the KSFs. These are factors that need to be managed and form part of organisers' event plans. These are also the factors that distinguish one event from the next. The outcomes of this process culminate in visitor satisfaction, high ticket sales - in short a successful event. Control (evaluation) may be the final step in management theory but not only does it determine the level of success but the feedback from the visitors also contribute to the sustainability of the festival and it is the starting point of future events (Saayman et al., 2010:97; Crompton and McKay, 1997:426; Raybould, 1998:238; Gitelson and Kerstetter, 2000:179). 
Figure 1: Relationship between planning and feedback

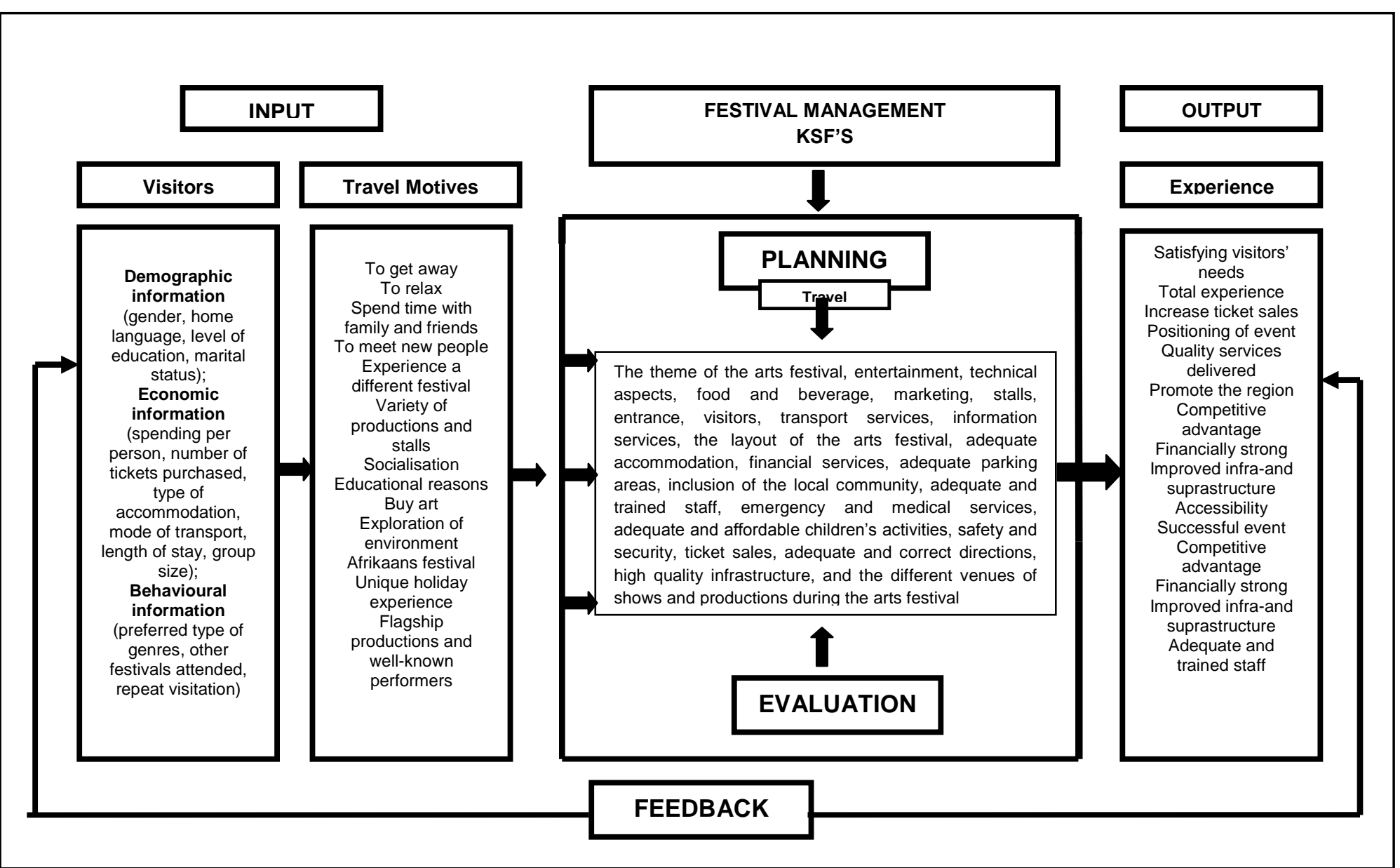

Source: Adapted from Saayman et al. (2010:97)

\section{THE PURPOSE OF THE RESEARCH}

The purpose of this research is thus to segment festival visitors at the Klein Karoo National Arts Festival (KKNK) based on their travel motives and their ratings of the Key Success Factors (KSFs) in terms of their festival experience.

\section{METHOD OF RESEARCH}

Quantitative research was conducted using a structured questionnaire to collect the data.

\section{The questionnaire}

The questionnaire used at the KKNK 2010 was based those suggested by Marais (2009), Silvers (2004:41); Matthews (2008:2); Bowdin et al. (2006:353) and Woodside and Martin (2008:206) and was made up of four sections. Section A consisted of the demographic information (gender, year of birth, home language, occupation, town/city of residence, province, how many years the festival have been 
visited, how many days stayed at the festival, nights stayed in Oudtshoorn, spending, preferred genres of shows). Section B focused on evaluating 52 aspects of the festival; thus the key success factors according to a five point Likert scale $(1=$ totally disagree, $2=$ do not agree, $3=$ neutral, $4=$ agree and 5 = totally agree); and section C measured the travel motivations. Twenty one travel motivations were measured with a five point Likert scale according to the importance of these motivations in the visitors' decision making process $(1=$ not at all important, $2=$ less important, $3=$ important, $4=$ very important and $5=$ extremely important).

\section{Sampling method and survey}

A destination-based survey was conducted where the questionnaires were handed out by nine field workers who were trained and who understood the aim of the study as well as the questionnaire. The survey took place at concert areas, festival grounds where visitors gathered between shows and at different food and beverage stalls and tents. Adult visitors were randomly selected as they entered or left these areas; respondents were briefed about the purpose of the research beforehand to ensure that they complete the questionnaire willingly and responded openly and honestly. A total of 443 questionnaires were completed over a period of eight days (1-8 April 2010). According to Israel (2009:6), when the population (N) is 100000,398 respondents $(n)$ is representative, with a 95\% level of confidence and a $\pm 5 \%$ sampling error. Thus the 443 completed questionnaires are therefore greater than the required number of questionnaires. Microsoft ${ }^{\odot}$ Excel $^{\odot}$ was used to capture the data and conduct a basic data analysis.

\section{Statistical analysis}

SPSS (SPSS Inc, 2007) was used for the analysis of the data. This study consists of three stages of statistical analyses. First, a principal axis factor analysis and a principal component factor analysis, using an Oblimin rotation with Kaiser Normalisation was performed on respectively the 52 critical success factors and the 21 motivations listed to explain the variance-covariance structure of a set of variables through a few linear combinations of these variables. The Kaiser-Meyer-Olkin (KMO) measure of sampling adequacy, as well as Bartlett's Test of Sphericity was used to determine if the covariance matrix is suitable for factor analysis. Kaiser's criteria were used for the extraction of all factors with eigenvalues larger than one; this is because they were considered to explain a significant amount of variation in the data. Any item that cross-loaded on more than one factor was categorised by the factor where its interpretability was best. A reliability coefficient (Cronbach's Alpha) was computed for each factor to estimate the internal consistency of each factor. All factors with a reliability coefficient above 0.6 were considered as acceptable and the average inter-item correlations were also computed as another measure of reliability and should be between 0.15 and 0.55 (Clark and Watson, 1995).

Secondly, a cluster analysis, using Ward's method with Euclidean distances, was performed on the travel motives' scores. Hair, Bush and Ortinay (2000:594) define a cluster analysis as a multivariate interdependence technique whose primary objective is to classify objects into relatively homogeneous groups based on the set variables considered. Lastly, multivariate statistics were used to examine the statistically significant differences between the motivational clusters. Two-way frequency tables and Chi-square tests were conducted to profile the clusters demographically, and ANOVAs with Tukey's multiple comparison were conducted to investigate and determine any significant differences between the clusters concerning factor scores. This study used demographic variables (gender, home language, age, occupation and province of origin), behavioural variables (length of stay, genres of shows and spending) and KSFs to examine whether statistically significant differences existed among the different groups.

\section{ANALYSIS AND INTERPRETATION OF FINDINGS}

The results will be discussed in three sections. First, the results of the factor analyses (critical success factors and travel motivations) will be discussed, followed by the results of the cluster analysis and lastly, the profiles of the clusters will be presented and discussed. 


\section{Results from the factor analysis Key Success Factors in managing the visitor experience}

The pattern matrix of the principal axis factor analysis identified seven factors using an Oblimin rotation with Kaiser normalisation namely Safety and Personnel, Marketing and Accessibility, Venues, Accommodation and Ablution, General Aspects and Social Impact, Parking and Restaurants, and Shows and Stalls. The seven factors accounted for $55,4 \%$ of the total variance and all factors had relatively high reliability coefficients, ranging from 0.83 (the lowest) to 0.88 (the highest). All the items loaded on a factor with a factor loading greater than 0.2. The Kaiser-Meyer-Olkin (KMO) measure of sampling adequacy of 0.94 also indicates that patterns of correlation are relatively compact and yield distinct and reliable factors (Field, 2005:640). Bartlett's Test of Sphericity also reached statistical significance $(p<0.001)$.

\section{Table1: Factor analysis of the key success factors}

\begin{tabular}{|c|c|c|c|}
\hline KEY SUCCESS FACTORS AND ITEMS & $\begin{array}{l}\text { FACTOR } \\
\text { LOADINGS }\end{array}$ & $\begin{array}{l}\text { MEAN } \\
\text { VALUE }\end{array}$ & $\begin{array}{l}\text { RELIABILITY } \\
\text { COEFFICIENT }\end{array}$ \\
\hline \multicolumn{2}{|l|}{ Factor 1: Safety and Personnel } & 3.78 & 0.88 \\
\hline Staff appears professional & 0.71 & & \\
\hline Friendly and helpful staff & 0.69 & & \\
\hline $\begin{array}{l}\text { Adequate number of staff members available during } \\
\text { festival }\end{array}$ & 0.68 & & \\
\hline $\begin{array}{l}\text { Staff are trained and informed to handle any queries } \\
\text { concerning the festival }\end{array}$ & 0.65 & & \\
\hline Police and security are in clear sight on festival terrain & 0.51 & & \\
\hline Precautions are taken in terms of street children & 0.40 & & \\
\hline High quality service at ticket sales & 0.33 & & \\
\hline Adequate safety precautions in place during festival & 0.31 & & \\
\hline Emergency services are visible & 0.24 & & \\
\hline Factor 2: Marketing and Accessibility & & 3.57 & 0.85 \\
\hline Adequate marketing before and during the festival & 0.20 & & \\
\hline Correct information given through marketing & 0.24 & & \\
\hline Adequate information centres on festival terrain & 0.77 & & \\
\hline Adequate information boards on festival terrain & 0.77 & & \\
\hline $\begin{array}{l}\text { Clear indications to halls, social venues and open-air } \\
\text { theatres }\end{array}$ & 0.61 & & \\
\hline Halls are easy accessible & 0.31 & & \\
\hline Layout of festival terrain is good & 0.26 & & \\
\hline Factor 3: Venues & & 3.77 & 0.87 \\
\hline Correct information is captured on tickets & 0.22 & & \\
\hline Front-of-house service at shows is good & 0.47 & & \\
\hline Seats in halls are numbered correctly & 0.46 & & \\
\hline Adequate amount of halls available & 0.44 & & \\
\hline Website is user friendly & 0.44 & & \\
\hline Adequate air-conditioning in halls & 0.42 & & \\
\hline Adequate amount of seats in halls & 0.40 & & \\
\hline Adequate amount of banks and mobile ATMs & 0.35 & & \\
\hline $\begin{array}{l}\text { Good technical aspects during shows (lights, sound } \\
\text { etc.) }\end{array}$ & 0.34 & & \\
\hline
\end{tabular}




\begin{tabular}{|c|c|c|c|}
\hline Effective booking of tickets through the internet & 0.21 & & \\
\hline Factor 4: Accommodation and Ablution & & 3.50 & 0.88 \\
\hline Adequate ablution facilities & 0.72 & & \\
\hline Good hygiene of ablution facilities & 0.68 & & \\
\hline Affordable prices for accommodation & 0.55 & & \\
\hline Adequate accommodation facilities available & 0.46 & & \\
\hline Effective marketing of accommodation & 0.42 & & \\
\hline Quality accommodation facilities & 0.41 & & \\
\hline Factor 5: Activities and community & & 3.66 & 0.86 \\
\hline Adequate activities and products for children & 0.25 & & \\
\hline Adequate control over alcohol use & 0.29 & & \\
\hline Local community's contribution is visible at the festival & 0.80 & & \\
\hline Local community is involved in festival & 0.80 & & \\
\hline Affordable prices of transport services & 0.40 & & \\
\hline Children's' activities are affordable & 0.34 & & \\
\hline Adequate transport services available for tourists & 0.28 & & \\
\hline Factor 6: Parking and Restaurants & & 3.68 & 0.83 \\
\hline Good safety of vehicles in parking areas & 0.57 & & \\
\hline Adequate parking on and around festival terrain & 0.54 & & \\
\hline $\begin{array}{l}\text { Adequate amount of dustbins available on festival } \\
\text { terrain }\end{array}$ & 0.53 & & \\
\hline Affordable prices at food providers & 0.42 & & \\
\hline Adequate food providers on the festival terrain & 0.34 & & \\
\hline Quality food at food providers & 0.25 & & \\
\hline Factor 7: Quality Shows and Stalls & & 3.80 & 0.84 \\
\hline Wide variety of shows are available & 0.53 & & \\
\hline High quality shows & 0.52 & & \\
\hline Products sold at stalls are affordable & 0.39 & & \\
\hline Affordable prices for shows & 0.38 & & \\
\hline Stall owners are friendly and supportive & 0.35 & & \\
\hline Quality products sold at stalls & 0.34 & & \\
\hline Wide variety of stalls and shops available & 0.32 & & \\
\hline TOTAL VARIANCE EXPLAINED & $55,4 \%$ & & \\
\hline
\end{tabular}

The factor scores were calculated as the average of all items contributing to a specific factor in order to interpret them on the original 5 -point Likert scale of measurement ( $1=$ Totally disagree; $2=$ Do not agree; $3=$ Neutral; $4=$ Agree; $5=$ Totally agree). As shown in Table 2, the following KSFs were identified: Safety and Personnel, Marketing and Accessibility, Venues, Accommodation and Ablution, Activities and Community, Parking and Restaurants and Quality Shows and Stalls. Shows and Stalls, Venues and Safety and Personnel were rated the most important according to visitors at the KKNK. Shows and Stalls and Parking and Restaurants were furthermore identified as unique success factors for arts festivals. Marketing and Accessibility and Accommodation and Ablution were rated the least important. The afore-mentioned contributes to the overall experience of visitors at the festival.

\section{Results from the factor analysis: Visitor Motivation}

Three motivational factors were identified when performing the pattern matrix of the principal component factor analysis using an Oblimin rotation with the Kaiser Normalisation. These factors were labelled according to similar characteristics (Table 2). The three factors accounted for $53,3 \%$ of the total variance. All factors have high reliability coefficients ranging from 0.77 (the lowest) to 0.88 (the highest). The average inter-item correlations values are between 0.40 and 0.43 ; this also implies that there is internal consistency for all the factors. The Kaiser-Meyer-Olkin measure of sampling adequacy 
M.Saayman

M. Kruger

J. Erasmus
Finding the key to success:

A visitors' perspective at a national arts festival

of 0.91 and Barlett's Test of Sphericity also reached statistical significance $(p<0.001)$, also indicated that patterns of correlation are relatively compact and should yield distinct and reliable factors (Field, 2005:640; Pallant, 2007:197).

Table 2: Factor analysis results of KKNK visitors' travel motivations

\begin{tabular}{|c|c|c|c|c|}
\hline $\begin{array}{l}\text { MOTIVATION FACTORS } \\
\text { AND ITEMS }\end{array}$ & $\begin{array}{l}\text { FACTOR } \\
\text { LOADINGS }\end{array}$ & $\begin{array}{l}\text { MEAN } \\
\text { VALUE }\end{array}$ & $\begin{array}{l}\text { RELIABILITY } \\
\text { COEFFICIENT }\end{array}$ & $\begin{array}{l}\text { AVERAGE } \\
\text { INTER-ITEM } \\
\text { CORRELATION }\end{array}$ \\
\hline $\begin{array}{l}\text { Factor 1: Festival } \\
\text { Attractiveness }\end{array}$ & & 3.87 & 0.88 & 0.42 \\
\hline $\begin{array}{l}\text { ABSA KKNK is different to } \\
\text { other festivals }\end{array}$ & 0.60 & & & \\
\hline Variety of productions & 0.80 & & & \\
\hline Quality productions & 0.74 & & & \\
\hline Sociable festival & 0.55 & & & \\
\hline $\begin{array}{l}\text { To see well-known } \\
\text { performers }\end{array}$ & 0.55 & & & \\
\hline $\begin{array}{l}\text { It is an annual } \\
\text { commitment }\end{array}$ & 0.44 & & & \\
\hline $\begin{array}{l}\text { It is primarily an Afrikaans } \\
\text { festival }\end{array}$ & 0.55 & & & \\
\hline $\begin{array}{l}\text { The festival provides a } \\
\text { unique holiday experience }\end{array}$ & 0.52 & & & \\
\hline $\begin{array}{l}\text { The introduction of new } \\
\text { flagship productions at the } \\
\text { festival }\end{array}$ & 0.50 & & & \\
\hline $\begin{array}{l}\text { The festival promotes } \\
\text { cultural inclusiveness }\end{array}$ & 0.41 & & & \\
\hline $\begin{array}{l}\text { The festival is value for } \\
\text { money }\end{array}$ & 0.63 & & & \\
\hline Factor 2: Novelty & & 3.17 & 0.79 & 0.43 \\
\hline $\begin{array}{l}\text { It is the closest festival for } \\
\text { me }\end{array}$ & 0.49 & & & \\
\hline $\begin{array}{l}\text { To the benefit of my } \\
\text { children }\end{array}$ & 0.59 & & & \\
\hline To support the stalls & 0.51 & & & \\
\hline To buy art & 0.78 & & & \\
\hline $\begin{array}{l}\text { To explore the } \\
\text { environment }\end{array}$ & 0.63 & & & \\
\hline $\begin{array}{l}\text { Factor 3: Escape and } \\
\text { Socialisation }\end{array}$ & & 3.84 & 0.77 & 0.40 \\
\hline $\begin{array}{l}\text { To get away from my } \\
\text { routine }\end{array}$ & 0.39 & & & \\
\hline To relax & 0.47 & & & \\
\hline To spend time with family & 0.46 & & & \\
\hline To spend time with friends & 0.60 & & & \\
\hline To meet new people & 0.42 & & & \\
\hline $\begin{array}{l}\text { TOTAL VARIANCE } \\
\text { EXPLAINED }\end{array}$ & $53,3 \%$ & & & \\
\hline
\end{tabular}


The factor scores were calculated as the average of all items contributing to a specific factor so that they could be interpreted on the original 5-point Likert scale of measurement. Festival attractiveness (Factor 1) had the highest mean value (3.87) and was considered as the most important motive for visitors to attend the festival. This was followed by Escape and Socialisation (Factor 3) (3.84). Novelty (Factor 2) obtained the lowest mean value (3.17) and was regarded as a less important motive.

\section{Results from the cluster analysis}

An exploratory cluster analysis based on all cases in the data was performed on the motivational factors. A hierarchical cluster analysis, using Ward's method of Euclidean distances, was used to determine the clusters' structures based on the motivation factors. A two-, three- and four-cluster solution was examined, and the three cluster solution was selected as the most discriminatory (Figure 2). The results of the multivariate analyses were used to identify the three clusters and to indicate that significant differences existed between them $(p<0.05)$.

Figure 2: Five cluster solution: Ward's method with Squared Euclidean distance measures

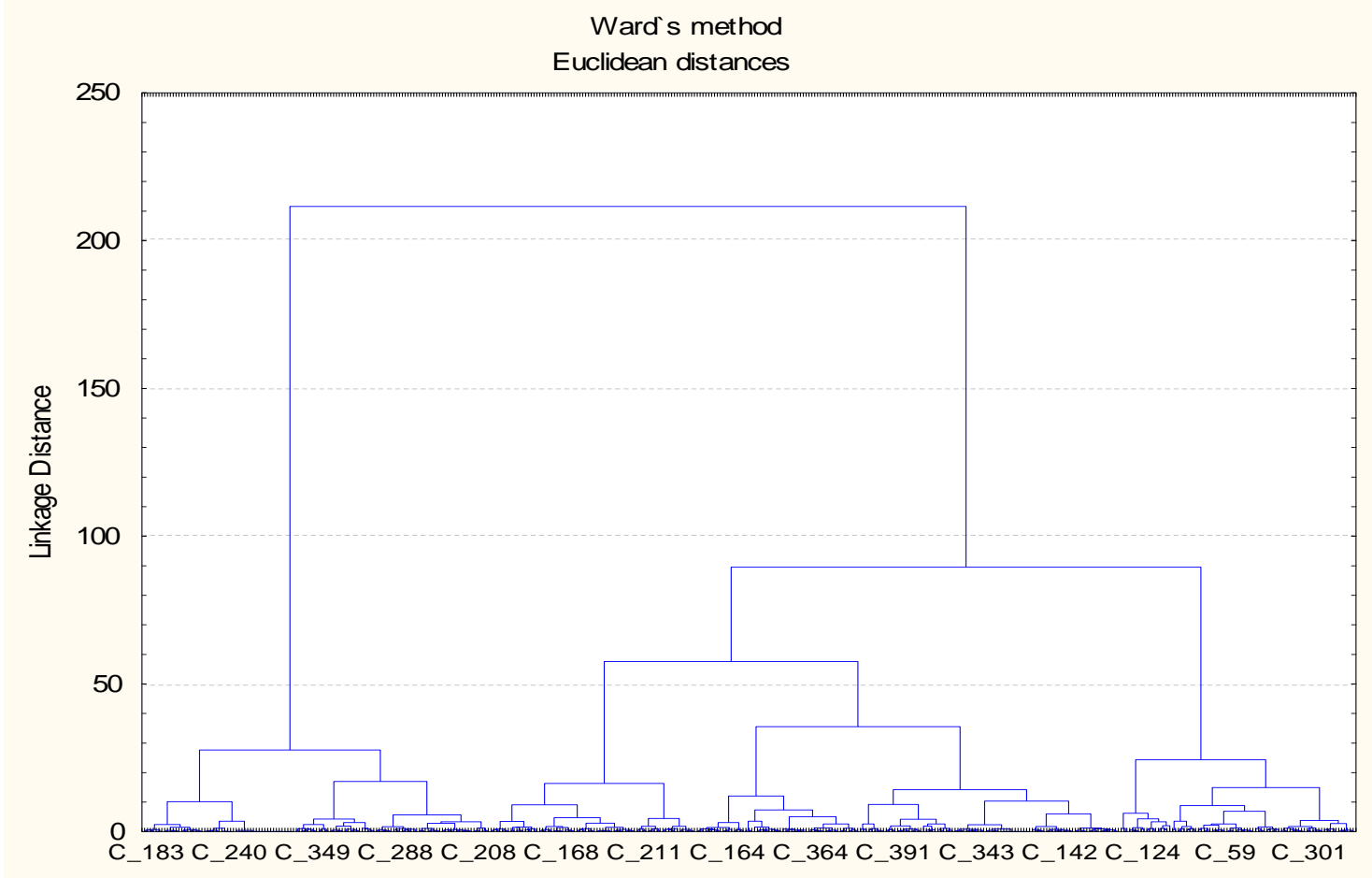

\section{Identification of segmented clusters}

ANOVAs of the three factors indicate statistical significant differences $(p<0.001)$. ANOVAs indicated that all three factors contributed to differentiating between the three motivational clusters $(p<0.05)$. In addition, Tukey's post hoc multiple comparisons were employed to explore these differences between clusters with regard to each factor. Table 3 indicates differences in means between the three clusters and reveals the importance of each of the factors for festival travel for the members of each cluster. 
Table 3: ANOVA and Tukey's post hoc multiple comparison results for motivational factors in three clusters of KKNK visitors

\begin{tabular}{|l|l|l|l|l|l|}
\hline Motivational factors & $\begin{array}{l}\text { Cluster 1 } \\
\text { Escapists } \\
(\mathbf{N}=130)\end{array}$ & $\begin{array}{l}\text { Cluster 2 } \\
\text { Festival } \\
\text { Junkies } \\
(\mathbf{N}=197)\end{array}$ & $\begin{array}{l}\text { Cluster 3 } \\
\text { Culture } \\
\text { seekers } \\
(\mathbf{N}=96)\end{array}$ & F-ratio & Sig. level \\
\hline Festival Attractiveness & $2.99^{\mathrm{a}}$ & $4.34^{\mathrm{b}}$ & $4.06^{\mathrm{c}}$ & 238.546 & $<0.05$ \\
\hline Novelty & $2.35^{\mathrm{a}}$ & $4.12^{\mathrm{b}}$ & $2.27^{\mathrm{a}}$ & 399.109 & $<0.05$ \\
\hline Escape and Socialisation & $2.96^{\mathrm{a}}$ & $4.35^{\mathrm{b}}$ & $2.27^{\mathrm{C}}$ & 219.092 & $<0.05$ \\
\hline
\end{tabular}

Note: respondents were asked to indicate how important they considered each item on the scale (1=not at all important, 2=less important, $3=$ important, $4=$ very important and $5=$ extremely important). Tukey's multiple comparisons indicate that statistically significant differences exist among the clusters with different superscripts. For example, in terms of Festival attractiveness, differences were found between Cluster 1 (superscript a) and all the other clusters. Cluster 2 (superscript b) differed from all the other clusters and Cluster 3 (superscript c) differed from all the other clusters as well.

Cluster 1 was labelled Escapists. This cluster contained 130 respondents and had the lowest mean values for all three of the travel motives (Festival attractiveness (2.99); Novelty (2.35); and Escape and Socialisation (2.96)). Cluster 2 was labelled the Festival Junkies, contained 197 respondents and had the highest mean scores for all the factors among the three cluster groups. Cluster 3 was labelled the Culture Seekers and contained 96 respondents. Within this cluster, Festival Attractiveness (4.06) had a significant larger mean than all the other factors. Table 3 also shows that all three clusters placed higher importance on Festival Attractiveness and Escape and Socialisation than on Novelty. The cluster analysis identified the most significant market segment as the Festival Junkies (Cluster 2). The Festival Junkies are characterised by having the highest mean scores across the three motivation factors and contained the largest sample of respondents.

\section{Results of ANOVA and Tukey's post hoc multiple comparisons}

ANOVAs were also conducted to determine the differences in other characteristics and the key success factors of visitors. As shown in Table 4, there were statistically significant differences between the Escapists, Festival Junkies and Culture Seekers based on all the characteristics. The results of this analysis revealed the following:

- Age: Based on age $(p<0.001)$ both Escapists (Cluster 1$)$ and Culture Seekers (Cluster 3) differ statistically from Festival Junkies (Cluster 2). The Escapists and Culture Seekers are, on average, in their early forties (41 and 40 years respectively), while the Festival Junkies are slightly older (47 years old).

- Years attended: With regard to years attended $(p<0.033)$ there were statistical significant differences according to the significance level. However, Tukey's post hoc comparison tests identified no differences between the three clusters. All three clusters indicated that they have attended the arts festival regularly for between five and six years.

- Length of stay: With regard to both the number of days spent at the festival $(p<0.010)$ and nights in Oudtshoorn $(p<0.002)$, both Escapists (Cluster 1) and Festival Junkies (Cluster 2) differ statistically from Culture Seekers (Cluster 3). The Culture Seekers stay approximately five days and nights at the arts festival, while Escapists and Festival Junkies stay an average of four days and the Escapists stay over in Oudtshoorn for four nights and the Festival Junkies for only three nights.

- Total spending: Based on total spending $(p<0.004)$ there were statistical significant differences between Escapists (Cluster 1) and Culture Seekers (Cluster 3). However there were no statistically significant differences between Escapists and Festival Junkies (Cluster 2) and between Culture Seekers and Festival Junkies. The Culture Seekers spent the most during the arts festival (R4770.44), followed by the Escapists, (R3774.70) and then the Festival Junkies (R3215.31).

- Key Success Factors: 
With regard to the KSFs, there were statistically significant differences based on all seven factors. These differences are discussed below:

$\checkmark$ Safety and Personnel $(p<0.05)$ : Escapists differ statistically from Festival Junkies and Culture Seekers. The Escapists (3.34) are neutral in agreement compared to Festival Junkies (4.01) and Culture Seekers (3.89) who agree that Safety and Personnel is an important factor for the success of the KKNK.

$\checkmark$ Marketing and Accessibility $(p<0.05)$ : With regard to this KSF, all three clusters differ statistically from one another. Festival Junkies (3.83) and Culture Seekers (3.58) agreed that Marketing and Accessibility is an important KSF for the KKNK compared to the Escapists who are neutral in agreement.

$\checkmark$ Venues $(p<0.05)$ : Festival Junkies and Culture Seekers differ significantly from Escapists. Escapists (3.46) do not have an opinion (neutral) on Venues in comparison with Festival Junkies (3.93) and Culture Seekers (3.82) who agree that Venues play an important role in the visitor experience at the festival.

$\checkmark$ Accommodation and Ablution $(p<0.05)$ : Escapists and Culture Seekers differ significantly from Festival Junkies. Regarding Accommodation and Ablution Escapists (3.22) and Culture Seekers (3.42) are neutral in their agreement that this KSF plays a role in the success of the KKNK. Festival Junkies (3.71), on the other hand, agree that Accommodation and Ablution is important, and that it contributes to their overall experience.

$\checkmark$ General Aspects and Social Impact $(p<0.05)$ : Significant statistical differences were identified between all three (Escapists, Festival Junkies and Culture Seekers). Festival Junkies (3.92) and Culture Seekers (3.65) both agree that General Aspects and Social Impact plays a role in satisfying the visitors needs. However Escapists (3.31) differ from this conclusion and for them it is neither important nor less important.

$\checkmark \quad$ Parking and Restaurants $(p<0.05)$ : Both Festival Junkies and Culture Seekers differ significantly from Escapists. Escapists (3.35) has a neutral agreement with regard to this KSF while, Festival Junkies (3.87) and Culture Seekers (3.71) agreed that it is an important factor contributing to their festival experience.

$\checkmark$ Shows and Stalls $(p<0.05)$ : With regard to Shows and Stalls, Escapists differ statistically from both Festival Junkies and Culture Seekers. Escapists (3.44) are neutral about whether Shows and Stalls are important in creating a unique experience for visitors to the KKNK, compared to Festival Junkies (4.00) and Culture Seekers who agree that Shows and Stalls are important. With regard to the KSFs the Festival Junkies rated all the factors the highest, followed by the Culture Seekers and the Escapist who rated all the factors the lowest. 
Table 4: ANOVA and Tukey's post hoc multiple comparison results for visitor characteristics and key success factors of the clusters

\begin{tabular}{|c|c|c|c|c|c|}
\hline Characteristics & $\begin{array}{l}\text { Cluster } 1 \\
\text { Escapists } \\
(\mathrm{N}=130)\end{array}$ & $\begin{array}{l}\text { Cluster } 2 \\
\text { Festival } \\
\text { Junkies } \\
(\mathrm{N}=197)\end{array}$ & $\begin{array}{l}\text { Cluster } 3 \\
\text { Culture } \\
\text { seekers } \\
(\mathrm{N}=96)\end{array}$ & F-ratio & $\begin{array}{l}\text { Sig. } \\
\text { level }\end{array}$ \\
\hline Age & $41^{a}$ & $47^{b}$ & $40^{\mathrm{a}}$ & 9.116 & 0.001 \\
\hline Years attended & 5 & 6 & 6 & 3.432 & $0.033^{*}$ \\
\hline $\begin{array}{c}\text { Length of stay } \\
\text { Days } \\
\text { Nights }\end{array}$ & $\begin{array}{l}4^{\mathrm{a}} \\
4^{\mathrm{a}}\end{array}$ & $\begin{array}{l}4^{\mathrm{a}} \\
3^{\mathrm{a}}\end{array}$ & $\begin{array}{l}5^{\mathrm{b}} \\
5^{\mathrm{b}}\end{array}$ & $\begin{array}{l}4.708 \\
6.352\end{array}$ & $\begin{array}{l}0.010^{*} \\
0.002^{*}\end{array}$ \\
\hline Total spending & $\mathrm{R} 3774.70^{\mathrm{a}}$ & $\mathrm{R} 3215.31^{\mathrm{ab}}$ & R4770.44 & 5.540 & $0.004^{*}$ \\
\hline \multicolumn{6}{|l|}{ Key Success Factors } \\
\hline Safety and Personnel & $3.34^{\mathrm{a}}$ & $4.01^{D}$ & $3.89^{b}$ & 47.793 & $<0.05$ \\
\hline Marketing and Accessibility & $3.23^{\mathrm{a}}$ & $3.83^{\mathrm{D}}$ & $3.58^{\mathrm{C}}$ & 26.600 & $<0.05$ \\
\hline Venues & $3.46^{\mathrm{a}}$ & $3.93^{\mathrm{D}}$ & $3.82^{b}$ & 23.924 & $<0.05$ \\
\hline Accommodation and Ablution & $3.22^{\mathrm{a}}$ & $3.71^{D}$ & $3.42^{\mathrm{a}}$ & 17.758 & $<0.05$ \\
\hline $\begin{array}{l}\text { General Aspects and Social } \\
\text { Impact }\end{array}$ & $3.31^{a}$ & $3.92^{b}$ & $3.65^{\mathrm{c}}$ & 31.875 & $<0.05$ \\
\hline Parking and Restaurants & $3.35^{\mathrm{a}}$ & $3.87^{D}$ & $3.71^{b}$ & 20.188 & $<0.05$ \\
\hline Shows and Stalls & $3.44^{\mathrm{a}}$ & $4.00^{\circ}$ & $3.85^{b}$ & 31.163 & $<0.05$ \\
\hline
\end{tabular}

* Statistically significant difference: $\mathrm{p} \leq 0.05$

Tukey's multiple comparisons indicate that statistically significant differences exist among the clusters with different superscripts. For example, in terms of Festival attractiveness, differences were found between Cluster 1 (superscript a) and all the other clusters. Cluster 2 (superscript b) differed from all the other clusters and Cluster 3 (superscript bc) differed from all the other clusters as well.

\section{Results of two-way frequency tables and Chi-square tests}

Two-way frequency tables and Chi-square tests were also constructed to provide a complete demographic profile and show whether significant demographic differences existed between the three clusters. According to Table 5 there are statistically significant differences between the three clusters based on gender $(p<0.045)$ and rock $(p<0.010)$ as a preferred type of show/production. Even though there are no statistical differences based on the other characteristics it can still be seen that the three clusters differ from each other.

These differences are discussed below:

- Gender: The majority of respondents were female, however males had the highest percentage (47\%) in Cluster 3 (Culture Seekers) between the three clusters.

- Language: All three of the visitor groups were mainly Afrikaans speaking.

- Province: The majority of Escapists, Festival Junkies and Culture Seekers resided in the Western Cape. Escapists and Festival Junkies had the highest percentages. Gauteng was identified as the second highest province for the Escapists and this result corresponds with total spending (Table 5) because they travelled the furthest. Eastern Cape was identified as the second highest province of origin for the Festival Junkies and Culture Seekers.

- Occupation: All three clusters are in a high-income occupation, whereas Escapists had the highest percentage of visitors in this category; this result also corresponds with their total spending (Table 3) where Escapists had the highest spending over the duration of the arts festival. However Escapists also had the highest percentage of visitors in a low-income occupation, and this explains there travel motives; they are only at the KKNK to enjoy themselves and the arts festival.

- Types of Shows/Productions: Culture Seekers were very interested in rock shows and this corresponds with their age (Table 4) hence they are the youngest cluster. Culture Seekers 
also had the highest percentage for attending Drama shows followed by Festival Junkies and Escapists. All three clusters also attended Music Theatre and Cabaret, and Comedy shows. In general Escapists interests were spread over all the genres and type of shows and productions, whilst Festival Junkies and Culture Seekers had specific genres and types of shows/productions they preferred to attend.

Based on the above mentioned results from the cluster analysis, the Festival Junkies (Cluster 2) and Culture Seekers (Cluster 3 ) can be regarded as the arts festival's most important markets. These clusters indicate that respondents are female, Afrikaans speaking, in their forties and from the Western Cape. These visitors are in a high-income occupation, stay an average of four to five days and nights at the arts festival and have attended the festival for six years. They attend music theatre and cabaret, drama and comedy shows and productions during their stay at the KKNK. 
Table 5: Visitor characteristics of clusters

\begin{tabular}{|c|c|c|c|c|c|c|c|}
\hline Characteristics & $\begin{array}{l}\text { Cluster } 1 \\
\text { Escapists } \\
(n=130)\end{array}$ & $\begin{array}{l}\text { Cluster } 2 \\
\text { Festival Junkies } \\
(\mathrm{n}=197)\end{array}$ & $\begin{array}{l}\text { Cluster } 3 \\
\text { Culture Seekers } \\
(n=96)\end{array}$ & $\begin{array}{l}\text { Chi- } \\
\text { square } \\
\text { value }\end{array}$ & df & $\begin{array}{l}\text { Significance } \\
\text { level }\end{array}$ & Phi-value \\
\hline Gender & & & & 6.219 & 2 & $0.045^{*}$ & 0.121 \\
\hline Male & $38 \%$ & $32 \%$ & $47 \%$ & & & & \\
\hline Female & $62 \%$ & $68 \%$ & $53 \%$ & & & & \\
\hline Language & & & & 2.664 & 4 & 0.616 & 0.080 \\
\hline Afrikaans & $95 \%$ & $95 \%$ & $94 \%$ & & & & \\
\hline English & $4 \%$ & $5 \%$ & $6 \%$ & & & & \\
\hline Other & $1 \%$ & $0 \%$ & $0 \%$ & & & & \\
\hline Province & & & & 10.336 & 6 & 0.111 & 0.163 \\
\hline Western Cape & $65 \%$ & $65 \%$ & $51 \%$ & & & & \\
\hline Gauteng & $18 \%$ & $12 \%$ & $16 \%$ & & & & \\
\hline Eastern Cape & $14 \%$ & $18 \%$ & $29 \%$ & & & & \\
\hline Free State & $3 \%$ & $5 \%$ & $4 \%$ & & & & \\
\hline Occupation & & & & 4.947 & 4 & 0.293 & 0.108 \\
\hline $\begin{array}{l}\text { High-Income (Professional, } \\
\text { Management, Self-employed) }\end{array}$ & $48 \%$ & $39 \%$ & $44 \%$ & & & & \\
\hline $\begin{array}{l}\text { Medium-Income (Technical, Sales, } \\
\text { Farmer, Mining, Administrative, } \\
\text { Civil service, Education) }\end{array}$ & $19 \%$ & $29 \%$ & $28 \%$ & & & & \\
\hline $\begin{array}{l}\text { Low-Income (Housewife, Pensioner, } \\
\text { Student, Unemployed) }\end{array}$ & $33 \%$ & $32 \%$ & $28 \%$ & & & & \\
\hline \multicolumn{8}{|l|}{ Type of shows/productions } \\
\hline Drama & Yes=29\%;No=71\% & Yes=31\%;No=69\% & Yes $=43 \% ; \mathrm{No}=57 \%$ & 5.681 & 2 & 0.058 & 0.116 \\
\hline Dance Theatre & Yes $=11 \% ; \mathrm{No}=89 \%$ & Yes $=11 \% ; \mathrm{No}=89 \%$ & Yes $=12 \% ; \mathrm{No}=88 \%$ & 0.028 & 2 & 0.986 & 0.008 \\
\hline
\end{tabular}


Finding the key to success:

M. Kruger

A visitors' perspective at a national arts festival

\begin{tabular}{|c|c|c|c|c|c|c|c|}
\hline Word art \& Poetry & Yes=5\%; No=95\% & Yes=7\%;No=93\% & Yes $=5 \% ; \mathrm{No}=95 \%$ & 0.626 & 2 & 0.731 & 0.038 \\
\hline Children's Theatre & Yes=5\%; No=95\% & Yes $=3 \% ; \mathrm{No}=97 \%$ & Yes $=5 \% ; \mathrm{No}=95 \%$ & 1.622 & 2 & 0.444 & 0.062 \\
\hline Theatre discussions & Yes $=5 \% ; \mathrm{No}=95 \%$ & Yes=3\%;No=97\% & Yes $=5 \% ; \mathrm{No}=95 \%$ & 0.956 & 2 & 0.620 & 0.048 \\
\hline Music theatre \& Cabaret & Yes $=42 \% ; \mathrm{No}=58 \%$ & Yes $=42 \% ; \mathrm{No}=58 \%$ & Yes $=42 \% ; \mathrm{No}=58 \%$ & 0.010 & 2 & 0.995 & 0.005 \\
\hline Classical music & Yes $=12 \% ; \mathrm{No}=88 \%$ & Yes=11\%;No=89\% & Yes $=10 \% ; \mathrm{No}=90 \%$ & 0.089 & 2 & 0.956 & 0.015 \\
\hline Choir \& Ensemble & Yes=1\%;No=99\% & Yes=2\%;No=98\% & Yes $=0 \% ; \mathrm{No}=100 \%$ & 2.552 & 2 & 0.279 & 0.078 \\
\hline Rock & Yes=19\%;No=81\% & Yes=10\%;No=90\% & Yes=23\%;No=77\% & 9.151 & 2 & $0.010^{*}$ & 0.147 \\
\hline Visual arts \& Exhibitions & Yes $=6 \% ; \mathrm{No}=94 \%$ & Yes=5\%;No=95\% & Yes $=2 \% ; \mathrm{No}=98 \%$ & 2.138 & 2 & 0.343 & 0.071 \\
\hline Comedy & Yes $=29 \% ; \mathrm{No}=71 \%$ & Yes=22\%;No=87\% & Yes=31\%;No=69\% & 3.567 & 2 & 0.168 & 0.092 \\
\hline Jazz & Yes=1\%;No=99\% & Yes=2\%;No=98\% & Yes $=2 \% ; \mathrm{No}=98 \%$ & 0.906 & 2 & 0.636 & 0.046 \\
\hline
\end{tabular}

* Statistically significant difference: $p \leq 0.05$ 


\section{FINDINGS AND IMPLICATIONS}

The results from this research indicate that visitors to the KKNK are not homogeneous in terms of their travel motives and that different KSFs influence their experience differently. These results are consistent with the findings of Scott (1996), Rachael and Douglas (2001), Backman et al. (1995), Kara and Kaynak (1997), Marais (2009) and Formica and Murrmann (1998). These are the findings and implications based on the results:

First, three travel motives for attending the arts festival were identified, namely Festival Attractiveness, Novelty and Escape and Socialisation. Kruger (2009:29); Formica and Uysal (1998:19-21); Formica and Murrmann (1998:201-205); Lee, Lee and Wicks (2004:66); De Guzman, Leones, Tapia, Wong and De Castio (2006:864-865) also identified Festival Attractiveness as a travel motivation, while Novelty has also been identified by previous research including Formica and Uysal (1996); Formica and Uysal (1998:19-21); Formica and Murrmann (1998:201-205); Lee and Lee (2001:813-814); Lee et al. (2004:66); De Guzman et al. (2006:864-865) and Chang (2006:1229). Escape has been identified in research done by Lee et al. (2004:66); De Guzman et al. (2006:864-865); Uysal et al. (1994); Beh and Bruyere (2007); Saayman and Saayman (2008); and Kruger (2009:29), and Socialisation has also been identified by Formica and Uysal (1996); Formica and Uysal (1998:19-21); Formica and Murrmann (1998:201-205); Lee and Lee (2001:813-814); Lee et al. (2004:66); De Guzman et al. (2006:864-865); Chang (2006:1229) as a travel motive. However Escape and Socialisation have not been grouped together as a travel motive and is therefore a unique motive of visitors to the KKNK. Festival attractiveness was identified as the most important travel motive which shows the importance of the core business aspects of an arts festival, followed by Escape and Socialisation and, lastly, Novelty. This implies that travel motives differ from one event to the next, concurring with the findings by Saayman and Saayman (2006). Therefore organisers need to focus on the three motives mentioned above. It would also be advantageous if the marketing campaign focuses on these motives since they are unique to this festival.

Second, based on the identified travel motives, three distinct clusters and markets were identified namely Escapists, Festival Junkies and Culture Seekers. The Festival Junkies and Culture Seekers were identified as the most significant market segments since these visitors attend the KKNK specifically to experience arts and culture by means of shows and productions, stalls and socialisation. The results from the ANOVA furthermore revealed statistically significant differences between the Escapists, Festival Junkies and the Culture Seekers in terms of their socio-demographic and behavioural characteristics. In terms of the socio-demographic differences the Escapists and Culture Seekers are slightly younger than the Festival Junkies and want to experience shows and productions. The Culture Seekers spend more money at the festival compared to the Escapists and Festival Junkies and they rated Festival Attractiveness as their most important travel motivation. In terms of behavioural characteristics, Escapists, Festival Junkies and Culture Seekers indicated that they have attended the KKNK between five and six years, spending approximately five days and nights at the arts festival. This indicates a high level of loyalty among all clusters. The Culture Seekers were more interested in Rock shows compared to the other two clusters while three clusters were interested in Drama shows, Music theatre and Cabaret, and Comedy shows. The Culture Seekers attended different shows and productions during the festival, which implies that they are all-round festival goers who enjoy all types and genres of shows and productions, while Festival Junkies and Escapists had specific tastes in genres of shows and productions and festival organisers should therefore focus on providing high standard and quality shows in these specific genres to ensure the return of visitors in two clusters. The implication of this is that festival organisers need to implement a differentiated management and marketing strategy or plan to satisfy the needs of these clusters. In terms of the Festival Junkies, they should be encouraged to buy more tickets, since they are identified as the lowest spending cluster at the festival. This can be achieved by providing high quality affordable shows with well-known performers and including this in their marketing campaign before and during the festival. Festival Junkies are interested in genres including drama, musical theatre and cabaret and comedy shows, thus more of these shows should be included in the festival programme. Regarding the Culture Seekers festival organisers should encourage this cluster to stay longer at the festival, the festival has a duration of nine to ten days but the Culture Seekers only stay five nights and 
days at the festival; this can be achieved by offering special packages to visitors, which consist of accommodation, entrance to festival grounds, food and beverage and different shows they are interested in. Both Festival Junkies and Culture Seekers agree on the importance of the seven KSFs for the sustainability of the KKNK therefore festival organisers should focus on implementing and improving these KSFs in their management plan. Examples of what festival organisers can do include: training staff, providing adequate information services and kiosks across the festival grounds, using the best technical crews during shows and productions; placing ablution facilities on the festival grounds and ensuring they are in a good hygienic condition at all times; providing children's activities and packages consisting of children's activities, providing a greater variety of food and cold drinks and day care services. Since stalls are important, the introduction of new types of products at the festival should be managed and a floating trophy for best new product launched during the festival. This will encourage them to be innovative. These activities should contribute to the output phase as shown in Figure 1.

Last, as the results indicated that there are statistically significant differences between the three clusters of visitors based on the KSFs, this implies that a different approach is required. The Festival Junkies, for example had the highest mean values for all the KSFs and regard all seven KSFs as important for a quality visitor experience. The Escapists rated Venues and Shows and Stalls as the most important KSFs to improve their experience while Festival Junkies and Culture Seekers both identified Safety and Personnel and Shows and Stalls as necessary factors in creating a unique festival experience. The implication of the above is that a general evaluation of the success of an event can be misleading since visitors differ and the factors that contribute to their experience differ. A general evaluation merely indicates areas of importance but do not necessary distinguish the level of importance. If festival organisers want to ensure that visitors' needs are fulfilled, it means a more comprehensive approach has to be followed to ensure that the KSFs for different markets are determined.

\section{SUMMARY AND CONCLUSION}

The purpose of this study was to segment visitors to the KKNK by means of travel motives and showing that different markets have different requirements of a National Arts Festival. The findings of this study revealed that there are different types of travel motives visitors experience as important in their decision to visit the arts festival, namely Festival Attractiveness, Novelty and Escape and Socialisation. Furthermore, different markets have different travel motives, clustered as Escapists, Festival Junkies and Culture Seekers, and these different clusters have different tastes and needs, for example the Culture Seekers are more interested in Rock shows and all three the clusters enjoy Drama, Music Theatre and Cabaret and Comedy shows and productions. Different markets also focus on different KSFs that influence their experience of the event. Escapists rated Venues and Shows and Stalls as the most important KSF in managing the festival, whereas Festival Junkies and Culture Seekers rated Safety and Personnel and Shows and Stalls as the most important. The article makes several contributions; first, that travel motives are a good base or foundation for segmenting visitors to arts festivals; hence an in-depth understanding of why visitors attend the arts festival and what they expect to experience at the arts festival is important. Second, this research makes a contribution to the literature on travel motives, market segmentation, festival management and need satisfaction. Last, the results show that festival organisers cannot base their planning on a general evaluation of visitors but that different markets have different needs but they also regard factors contributing to their overall experience differently. Therefore, this research can help festival organisers to understand what visitors want to experience at the arts festival and how they want to experience it. 


\section{REFERENCES}

AAKER, D.A. 2005. Strategic market management. $7^{\text {th }}$ ed. N.Y.: Wiley. 356p.

BACKMAN, K. F., BACKMAN, S. J., UYSAL, M. and SUNSHINE, K. M. 1995. Event tourism: an examination of motivations and activities. Festival Management and Event Tourism, 3(1): 15-24.

BAKER, D. and CROMPTON, J. 2000. Quality, satisfaction and behavioural intentions. Annals of Tourism Research, 27(3): 425-439.

BANSAL, H. and EISELT, H. 2004. Exploratory research of tourist motivations and planning. Tourism Management, 25: 389-396.

BEH, A. and BRUYERE, B.L. 2007. Segmentation by visitor motivation in three Kenyan national reserves. Tourism Management, 28(6):1464-1471.

BOO, S. and JONES, D.L. 2009. Using a validation process to develop market segmentation based on travel motivation for major metropolitan areas. Journal of travel and tourism marketing, 26(1):60-79.

BOWDIN, G., ALLEN, J., O'TOOLE, W., HARRIS, R. and MCDONNEL, I. 2006. Events management. $2^{\text {nd }}$ ed. Oxford: Butterworth-Heinemann. 510p.

BROTHERTON, B., MILLER, K., HEINHUIS, E. and MEDEMA, M. 2002. Critical success factors in UK and Dutch Hotels. Journal of Service Research, 2(2): 47-78.

BROTHERTON. B. and SHAW, J. 1996. Towards an identification and classification of critical success factors in UK hotels Plc. International Journal of Hospitality Management, 15(2): 113-135.

CHA, S., McCLEARY, K. and UYSAL, M. 1995. Travel motivations of Japanese overseas travellers: a factor-cluster segmentation approach. Journal of Travel Research, 33(3):3-39.

CHANG, J. 2006. Segmenting tourists to aboriginal cultural festivals: an example in the Rukai tribal area, Taiwan. Tourism Management, 27(6):1224-1234.

CLARK, L.A. and WATSON, D. 1995. Constructing validity: basic issues in objective scale development. Psychology Assessment, 7(3):309-319.

CROMPTON, J. L. and MCKAY, S.L. 1997. Motives of visitors attending festival events. Annals of Tourism Research, 24: 425-439.

CROMPTON, J.L. and MCKAY, S.L. 1997. Motives for visitors attending festival events. Annals of Tourism Research, 24(2):425-439.

DAFT, R. L. and MARCIC, D. 2009. Management: the new workplace. Thomson: South-Western. 720p.

DE GUZMAN, A.B., LEONES, J.D., TAPIA, K.K.L., WONG, W.G. and DE CASTRO, B.V. 2006. Segmenting motivation. Annals of Tourism Research, 33(3):863-867.

DE WITT, L. 2006. Key success factors for managing special events: the case of wedding tourism. North-West University: Potchefstroom Campus. (Dissertation - MCom.) 128p. 
ERASMUS, L. J. J., SAAYMAN, M., SAAYMAN, A., KRUGER, M., VIVIERS, P., SLABBERT, E. and OBERHOLZER, S. 2010. The socio-economic impact of visitors to the ABSA KKNK in Oudtshoorn 2010. Potchefstroom. 75p. (Unpublished.).

FERRELL, O.C., HARTLINE, M.D. and LUCAS, G. 2002. Marketing Strategy. Thomson:SouthWestern. 469p.

FIELD, A. 2005. Discovering Statistics using SPSS. $2^{\text {nd }}$ ed. London: Sage Publications Ltd. $816 p$.

FORMICA, S. and MURRMANN, S. 1998. The effects of group membership and motivation on attendance: an international festival case. Tourism Analysis, 3(3-4):197-207.

FORMICA, S. and UYSAL, M. 1996. A market segmentation of festival visitors: Umbria Jazz Festival in Italy. Festival Management and Event Tourism, 3(4):175-182.

FORMICA, S. and UYSAL, M. 1998. Market segmentation of an International Cultural-historical event in Italy. Journal of Travel Research, 36(4): 16-24.

GITELSON, R. and KERSTETTER, D. 2000. A new perspective on the Decision-making process of Arts Festival visitors. (In Events Beyond 2000: Setting the Agenda. Proceedings of Conference on Event Evaluation, Research and Education, held in Sydney 2000.). Sydney. p. 183-189.

GNOTH, J. 1997. Tourism motivation and expectation formation. Annals of Tourism Research, 24(2): 283-304.

GOODMAN, S.H., FANDT, P.M., MICHTITSCH, J.F. and LEWIS, P.S. 2007. Management: challenges for tomorrow's leaders. $5^{\text {th }}$ ed. Thomson: South-Western. 553p.

HAIR, J.F., BUSH, R.P. and ORTINAU, D.J. 2000. Marketing research: a practical approach to the new millennium. Boston: Irwin/McGraw-Hill. 682p.

HAUPTFLEISCH, T. 2001. The eventification of Afrikaans culture - some thoughts on the Klein Karoo Nasionale Kunstefees (KKNK). South African Journal. 15: 169-177.

JANG, S. and WU, C.E. 2006. Seniors' travel motivation and the influential factors: an examination of Taiwanese seniors. Tourism Management, 27:306-316.

JUWAHEER, T.D. 2006. Using service quality expectations as a criterion to segment international tourists in the hospitality industry: an outlook of hotels of Mauritius. Journal of Travel and Tourism Marketing, 21(2/3):1-18.

KARA, A. and KAYNAK, E. 1997. Markets of a single customer: exploiting conceptual developments in market segmentation. European Journal of Marketing, 31(11/12):873-895.

KIM, H., BORGES, M. C. and CHON, J. 2006. Impacts of environmental values on tourism motivations: the case of FIFA, Brazil. Tourism Management, 27: 957-967.

KIM, K., UYSAL, M. and CHEN, J.S. 2002. Festival visitor motivation from the organisers' points of view. Event Management, 7(2):127-134.

KITSHOFF, H. 2004. Klein Karoo Nasionale Kunstefees (KKNK) - Oudtshoorn, 3-11 April 2004. SouthAfrican Travel Journal. 18: 237-241. 
KOC, E. and ALTINAY, G. 2007. An analysis of seasonality in monthly per person tourist spending in Turkish inbound tourism form a market segmentation perspective. Tourism Management, 28(1):227-237.

KREITNER, R. 1989. Management. Houghton Mifflin. 787p.

KRUGER, M. 2009. Spending behaviour of visitors to the Klein Karoo National Arts Festival. North-West University: Potchefstroom Campus. (Dissertation - MCom.) 86p.

KRUGER, M. and SAAYMAN, M. 2008. Travel motives of visitors attending Oppikoppi Music Festival. Acta academica. 41(4):56-73.

LEE C.K., LEE Y.K. and WICKS B.E. 2004. Segmentation of festival motivation by nationality and satisfaction. Tourism management, 25(1): 61-70.

LEE, C. 2000. A comparative study of Caucasian and Asian visitors to a cultural expo in an Asian setting. Tourism Management, 21(2):169-176.

LEE, C. and LEE, T. 2001. World Culture Expo segment characteristics. Annals of Tourism Research, 28(3):812-816.

LEIPER, N. 2004. Tourism Management. $3^{\text {rd }}$ ed. NSW: Pearson Hospitality Press. 455p.

MARAIS, M. 2009. Key success factors in managing the Wacky Wine Festival. North-West University: Potchefstroom Campus. (Dissertation - MCom.) 60p.

MATTHEWS, D. 2008. Special event production: the process. Oxford: Butterworth-Heinemann. 250p.

MOHR, K., BACKMAN, K.E., GAHAN, L. and BACKMAN, S.J. 1993. An investigation of festival motivations and event satisfaction by visitor type. Festival Management and Event Tourism, 1(1):89-98.

MURPHY, P. E. and MURPHY, A. E. 2004. Strategic management for tourism communities: bridging the gaps. Clevedon: Channel View Publications. 448p.

MYKLETUN, R.J., CROTTS, J.C. and MYKLETUN, A. 2001. Positioning an island destination in the peripheral area of the Baltics: a flexible approach to market segmentation. Tourism Management, 22(5):493-500.

NICHOLSON, R. and PEARCE, D. G. 2001. Why do people attend events: a comparative analysis of visitor motivations at four South Island events. Journal of Travel Research, 39(4): 449-460.

PAGE, J. 2003. Tourism Management: managing for change. Oxford: Butterworth-Heinemann. 381p.

PALLANT, J. 2007. SPSS Survival manual: a step-by-step guide to data analysis using SPSS version 15. $3^{\text {rd }}$ ed. N.Y.: McGraw-Hill. 335p.

PARK, K.S., REISINGER, Y. and KANG, H.J. 2009. Visitors' motivation for attending the South Beach Wine and Food Festival, Miami Beach, Florida. Journal of Travel and Tourism Marketing, 25(2):161-11.

PRENTICE. R. and ANDERSON, V. 2003. Festival as creative destination. Annals of Tourism Research, 30(1):7-30.

RACHAEL, E. and DOUGLAS, G. 2001. Why do people attend events: a comparative analysis of visitor motivation at four South Island events. Journal of Travel Research, 39(4):449-460. 
RACHAEL, E.N. and DOUGLAS, G.P. 2001. Why do people attend events: a comparative analysis of visitor motivations at four South Island events. Journal of Travel Research, 39(4):449-460.

RAYBOULD, M. 1998. Participant motivation in a remote fishing event. Festival Management and Event Tourism, 1(3):239-241.

SAAYMAN, M. 2001. Tourism marketing in South Africa. Potchefstroom: Leisure consultants and publications. 389p.

SAAYMAN, M. 2007. En Route with Tourism: an introductory text. Potchefstroom: Leisure Consultants and Publications. 356p.

SAAYMAN, M. 2009. Hospitality, Leisure and Tourism Management. Potchefstroom: Leisure Publications. 533p.

SAAYMAN, M. and SAAYMAN, A. 2008. Why travel motivations and socio-demographics matter in managing a National Park. Koedoe, 51(1):381-388.

SAAYMAN, M., MARAIS, M. and KRUGELL, W. 2010. Measuring success of a wine festival: is it really that simple? South African Journal for Research in Sport, Physical Education and Recreation, 32(2): 95107.

SCHNEIDER, I. E. and BACKMAN, S. J. 1996. Cross-Cultural equivalence of festival motivations: a case study in Jordan. Festival Management and Event Tourism, 4(3-4):139-144.

SCOTT, D. 1996. A comparison of visitor's motivations to attend three urban festivals. Festival Management and Event Tourism, 3:121-128.

SILVERS, J. 2004. Professional event co-ordination. New Jersey: John Wiley and Sons. 474p.

STEYN, H. S. 2000. Practical significance of the difference in means. Journal of Industrial Psychology, 26(3): 1-3.

THOMPSON, A.A. and STRICKLAND, A.J. 1999. Strategic management: concepts and cases. $11^{\text {th }}$ ed. Boston, Mass: Irwin/McGraw-Hill. 1049p.

UYSAL, M., GAHAN, L. and MARTIN, B. 1993. An examination of event motivations: a case study. Festival Management, 1(1):5-10.

VALLEN, L. K. and VALLEN, J. J. 2005. Check in Check out. Managing Hotel Operations. $7^{\text {th }}$ ed. New Jersey: Pearson Education. 636p.

VAN DER WESTHUIZEN, T. 2003. Key success factors for developing and managing a guesthouse. North-West University: Potchefstroom Campus. (Dissertation - Mcom.) 256p.

VAN ZYL, C. 2002. The participation of the host community in the Aardklop National Arts Festival. Unpublished MPhil dissertation. Pretoria: University of Pretoria.

VAN ZYL, C. 2005. Optimum market-positioning models for South African Arts festival scenarios. University of South Africa (Dissertation - PhD). 433p.

WesterbeEK, H., SMith, A., TURNeR, P., EMERY, P., GREeN, C. and VAN LEEUWEN, L. 2006. Managing sport facilities and major events. Oxon: Routledge. 278p. 
YU, L. and HUAT, G. S. 1995. Perceptions of management difficulty factors by expatriate hotel professionals in China. International Journal for Hospitality Management, 14(4): 375-388. 